\title{
OBSERVATIONS ON SOME RECENTLY DESCRIBED COCCIDAE.
}

\author{
By E. Ernest Green, F.E.S., F.Z.S.
}

Pseudococcus bicaudatus, Keuchenius, Medel. v.h. Besoekisch Proefstation, Djemba, No. 16, 1915, p. 63 [see also Review of Applied Entomology, Nov. 1915, p. 647].

The author's detailed description of the supposed new species shows quite clearly that he is dealing with Pseudococcus virgatus, described by Cockerell in 1893. The species occurs commonly throughout the tropics of both hemispheres and has been described by different authors under several names, e.g. ceriferus (Newstead), talini (Green), and marchali (Vayssière).

Fiorinia morrisi, Brittin, Trans. N.Z. Inst., Wellington, xlvii, 1914 (issued July 1915), p. 149 [see also Rev. Appl. Entom., Dec. 1915, p. 74].

Through the courtesy of the author, I have had an opportunity of examining typical examples of this insect, and find that they agree with examples of $F$. asteliae (ex coll. W. M. Maskell). Fiorinia asteliae is now considered to be a synonym of F. gigas of Maskell, and both have been rightly relegated to the genus Leucaspis.

Fiorinia maskelli, Brittin, loc. cit., p. 157.

After examination of specimens received from the author, $I$ am convinced that this species also should be referred to the genus Leucaspis. I append drawings of the posterior extremity of the nymph (fig. 1,a) and of the adult female (fig. 1, b). I am puzzled by the author's representation (loc. cit., fig. 3) of the pygidium of the adult female. It will be seen that this agrees, more or less, with my figure of the nymph, except that it shows circumgenital glands, which, of course, are never present in the nymphal stage. The species appears to be distinct, but approaches kermanensis of Lindinger.

Pinnaspis nitidus, Brittin, loc. cit., p. 151.

This proves to be Mytilaspis pyriformis of Maskell.

Lecanium armatum, Brittin, loc. cit., p. 152.

Mr. Brittin now informs me that he has been able to identify this insect with Maskell's Ctenochiton spinosus.

Scutare fimbriata, Brittin, loc. cit., p. 158.

I should refer this insect to the genus Rhizococcus. The author describes a "puparium," but I have failed to find (in specimens received from him) anything that can be compared to a true puparium. The dorsum of the insect has a very thin coating of translucent wax which gives it a pruinose appearance, and in the early 
adult female there is a more or less complete fringe of waxy lamellae. The latter character is merely an exaggeration of the condition found in Rhiz. pulchellus, in which species the marginal spines are said to give rise to long glassy tubes which form a fringe.
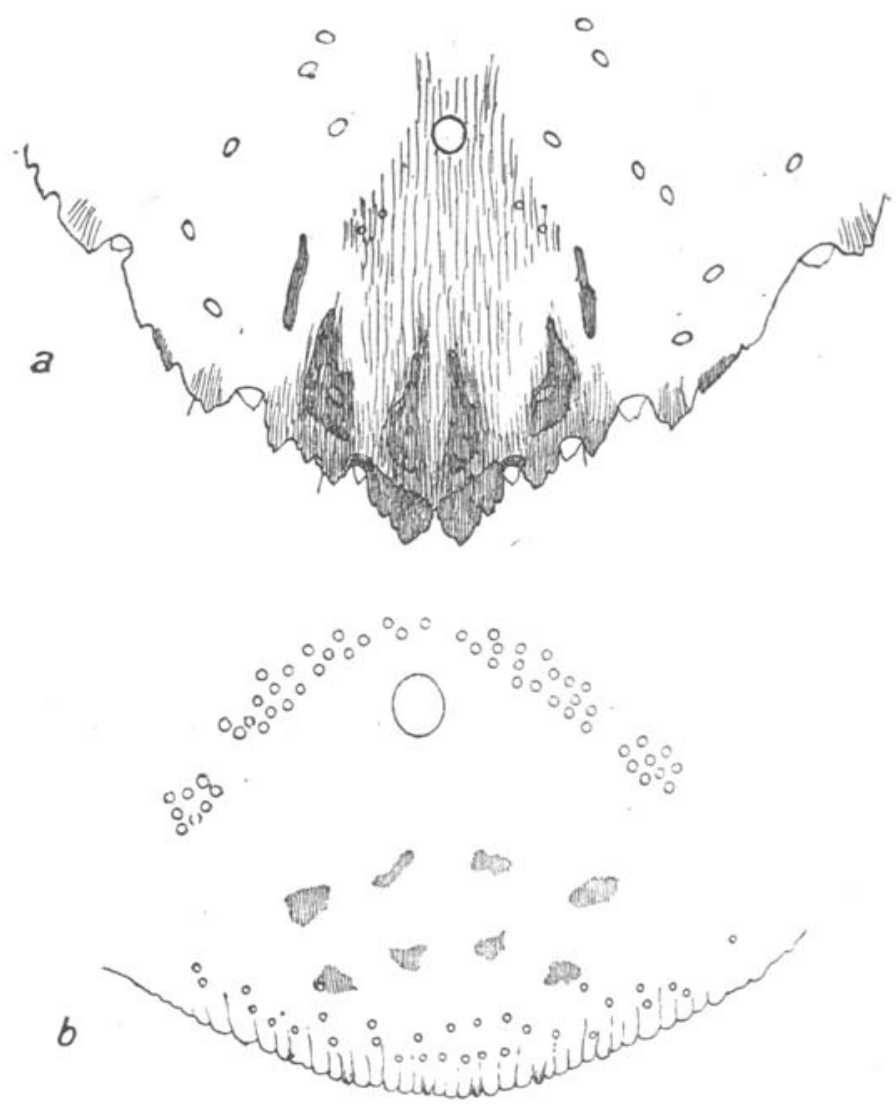

Fig. 1. Fiorinia maskelli, Brittin ; posterior extremity of $(a)$ nymph, (b) adult female ; $\times 280$.

Cryptococcus nudatus, Brittin, loc. cit., p. 160.

This name must fall to Maskell's Sphaerococcus parvus - now placed in the distinct genus Kuwanina. It is not surprising that Mr. Brittin failed to recognize his insect from Maskell's description and figures, which are quite inadequate and even misleading. 